UDK: 159.923.2.072

\title{
Future Self-Continuity Increases Responsibility During Covid-19 Restrictions
}

\author{
Andrej Simić ${ }^{1,2}$, Elvis Vardo ${ }^{1}$, and Šuajb Solaković ${ }^{3}$ \\ ${ }^{1}$ University of Tuzla, Tuzla, Bosnia and Herzegovina \\ ${ }^{2}$ University of Milano-Bicocca, Department of Psychology, Milan, Italy \\ ${ }^{3}$ University of East Sarajevo, Sarajevo, Bosnia and Herzegovina
}

\begin{abstract}
The failure to engage in responsible behaviour is related to the inability to consider future consequences of actions. An experiment was conducted to examine whether increasing the vividness of the future self affects adherence and endorsement of COVID-19 safety measures. A total of 184 participants were randomly assigned to 3 groups. Depending on the experimental condition, they were tasked with writing a letter to other people (their friend), a proximal future self, and a distant future self. Participants in the distant future self and the other people conditions showed greater adherence intentions than proximal future self participants. No differences were found between the distant future self and the other people group. Further group differences were found in the endorsement of safety measures, with the distant-future self-group showing more condemnation than the other two groups. Commitment to the COVID-19 safety measures mediated the group differences on both dependent variables. The results are discussed within the framework of the Construal Level Theory and the Future Self-continuity model.
\end{abstract}

Keywords: future self-continuity, intentions, responsible behaviour, goal commitment, COVID-19 safety measures

\section{Introduction}

Since the local outbreak in December 2019 in the city of Wuhan (Hubei, China), the coronavirus (COVID-19) has spread all over the world. At the time of writing this paper (May 2020), more than 4 million people have shown symptoms of the infection, while COVID-19 has taken 283,153 thousand lives (World Health Organization, 2020). The pandemic has resulted in major global and national changes in health, economic, and social systems. Governments introduced safety measures

Andrej Simić, Department of Psychology, Faculty of Humanities, University of Tuzla, Tihomila Markovića 1, 75000 Tuzla, Bosnia and Herzegovina. E-pošta: andrej.simic994@gmail.com 
popularly referred to as social distancing. These interventions aim to suppress the spread and thus reduce the virus incidence. Social distancing includes restrictions on movement and public gatherings, wearing protective equipment, and respecting selfisolation measures including a curfew.

Safety measures can be understood as external goals. They contain an ideal state that is pursued and are operationalized in structured and concrete terms (Locke \& Latham, 1990, 2002). For example, if the wearing of protective equipment is perceived as an externally set goal, the goal is realized when wearing masks and gloves in the open places, while the behaviour should be directed towards protective equipment. The problem with goals formulated in this way is that they lead to longterm profit at the cost of short-term sacrifices. Short-term compliance will not lead to significant progress in the fight against COVID-19, while long-term consequences will be significantly more positive than continued non-compliance (Reluga, 2010). As a result, people become less motivated to comply with safety measures. This paper will seek to identify mechanisms that can help increase compliance with COVID-19 safeguards and similar situations that require the sacrifice of short-term gains.

\section{Impatience as a Factor of Noncompliance}

In general, humans are impatient beings. Temporal discounting is used to describe the tendency to accept rewards that are close in time while devaluing other temporally distant rewards (Frederick et al., 2002). With all other things being equal, people prefer short-term gains rather than more distant rewards. The first approach to explaining temporal preference was provided by Samuelson (1937). According to his discount utility (DU) model, individuals make intertemporal choices by weighing their utility in the present. Future rewards are discounted because they are delayed and have lower perceived importance here and now. The model assumes that discount rates are constant over time - individuals will equally weigh rewards regardless of their temporal placement in the future and their characteristics. The simplicity of the DU model does not account for complex psychological factors influencing decision-making. Research has shown that discount rates decline over time (e.g., Benzion et al., 1989; Chapman \& Elstein, 1995; Thaler, 1981). Furthermore, it seems that temporal discounting is also related to the characteristics of rewards (Frederick et al., 2002). The hyperbolic discounting (HD) recognizes the fallacies of the DU model and proposes that individuals prefer immediate rewards in the short-term but are more patient when they consider the long-term outcomes of their decisions (Frederick et al., 2002; Kirby, 1997; Kirby \& Maraković, 1995). Several psychological mechanisms have been proposed to explain HD: impulsivity (Ainslie, 1975; Lowenstein, 1996), individual differences in cognitive representations of the future (Malkoc \& Zauberman, 2006), and subjective time perception (Zauberman et al., 2009). 
Studies have found that low temporal discounting is related to more responsible monetary decisions (e.g., Bartels \& Urminsky, 2015; Frederick et al., 2009; Zauberman et al., 2009). Also, a strand of research provided evidence that temporal discounting is present when making other decisions that require self-control. High levels of temporal discounting are related to risky sexual behaviour (Chesson et al., 2006), criminal offences (Arantes et al., 2013), substance (Yi et al., 2010), alcohol (Moore \& Cusens, 2010), and tobacco (Audrain-McGovern et al., 2009; Sheffer et al., 2012) abuse. The tendency to value immediate rewards over their delayed counterparts contributes to several negative outcomes in everyday life. In that regard, there should exist a strong interest in devising interventions to reduce temporal discounting.

According to the Construal Level Theory (CLT; Liberman \& Trope, 1998; Trope \& Liberman, 2003, 2010), individuals differently construct events depending on whether they are perceived to be more psychologically closer or distant. Highlevel construal are abstract representations that refer to the centrality, desirability, or the "why" aspect of behaviour and thus represent distant objects (Liberman \& Trope, 1998). On the other hand, low-level construal are more concrete, refer to contextual, incidental, or the "how" aspects of behaviour. They are used to understand more psychologically proximal concepts. Psychological distance can be observed on several dimensions: temporal, spatial, social, and hypothetical (Bar-Anan et al., 2006). Inside the CLT framework, the temporal distance is commonly used to explain impatience. Impatience can be understood as an emphasized focus on temporally proximal outcomes (Trope et al., 2007). Temporally distant behaviours will be evaluated by how close they are to an ideal state. In contrast, thinking about temporally closer behaviours might lead to the preference of present gratifications disregarding future events.

It seems that the construal level impacts individual differences in temporal discounting rates. Fujita and his colleagues (Fujita \& Han, 2009; Fujita et al., 2006) demonstrated that high-level construals led to a higher decrease in preferences for immediate over delayed benefits when compared to a concrete-construal condition. Yi et al. (2017) expanded on these findings and showed the concrete representation of delayed outcomes increased their perceived preference levels, while the abstract construal of present outcomes decreased their perceived valuation. Thinking about objects in abstract terms might be related to a lower valuation of immediate rewards, while low-level construals might increase the preferences for present gratifications.

For example, virus containment is perceived as the most desirable outcome for most people. Because it is constructed in abstract terms, emphasis is put on positive outcomes of safety measures adherence: keeping oneself and others healthy as well as helping to create a pandemic-free future. In other words, one becomes committed to these abstract rules due to positive, long-term outcomes. While adherence to safety measures is desirable, as it draws temporally closer, the individual might realize which concrete behaviours safety measures require. Thinking about the safety 
measures in concrete terms may increase the awareness of necessary sacrifices of certain freedoms. Examples include exclusion from friends and family members, losing free movement and financial stability, as well as specific alterations in day-today activities such as shopping, dietary habits, exercise, and social events.

\section{Future Self-Continuity}

One way of reducing temporal discounting is by highlighting one's responsibility to their future self. According to the multiple-self models, the selfconcept is composed of a corpus of overlapping selves (Bartels \& Rips, 2010; Elster, 1985; Hershfield et al., 2011; Parfit, 1971, 1984; Schelling, 1984; Thaler \& Shefrin, 1981). Each self is considered as a distinct entity that may or may not be strongly connected to other selves. Parfit (1984) suggested that individual differences which exist in the future self are perceived and evaluated. The main implication of this theory is that a future self can be perceived as an entirely different person depending on the degree of connectedness to it. Because people are not rationally required to put others' needs above theirs, a weak connection with a future self results in little consideration of its well-being when making present decisions. Studies that aimed to test this hypothesis suggested that the treatment of the future selves is no different than the treatment of other people (Burum et al., 2016; Pronin \& Ross, 2006; Pronin et al., 2008). In other words, people are motivated to keep all rewards to themselves rather than sharing benefits with others (including their future selves).

Two factors determine the degree of future self-continuity. The first one is the temporal distance (Bartels \& Rips, 2010; Pronin \& Ross, 2006). For example, Bartels and Rips (2010) found that psychological connectedness decreased when temporal distance increased. Participants in this study were more connected to their proximal future selves than their distant counterparts. Furthermore, a distant self is going to be perceived from a more observer-like perspective than a proximal future self (Pronin $\&$ Ross, 2006). The second factor is related to the perceived change in the future self. The more individuals perceive that their future selves will not change over time, the more connected they feel to their future selves (Bartels \& Rips, 2010; Bartels \& Urminsky, 2015).

Recent research examined the effect of future self-continuity on the facilitation of more responsible behavioural intentions and actions. It seems that when the future self is made salient, individuals make decisions that are more oriented toward future consequences. Ersner-Hershfield et al. (2009) found neuroimaging evidence that differences between current and future self predict temporal discounting. Van Gelder and colleagues demonstrated that the activation of the distant future self decreased delinquent behaviour in the laboratory (Van Gelder et al., 2013) and field settings (Van Gelder et al., 2015). Likewise, thinking about the future self reduced endorsement of unethical behaviour (Hershfield et al., 2012). 


\section{The Present Study}

Behaviours that lead to the adherence to COVID-19 safety measures are considered to be ethical and responsible. The virus is contained by adhering to prescribed safety measures. This paper aims to examine the effect of future selfcontinuity on the endorsement of COVID-19 behavioural measures. As in the studies by Pronin and Ross (2006), the condition of other people is introduced as a reference point to compare the effectiveness of future self-continuity interventions.

First, by making the abstract, distant future self more salient, one could bring to mind the abstract safety measures rules and promote adherence to them (Fujita et al., 2006; Trope \& Liberman, 2003, 2010; Yi et al., 2017). In other words, activation of a distant future self should have a larger effect on adherence intentions than a) vividness of the proximal future self and $b$ ) vividness of other people. Second, in line with recent research (e.g., Hersfield et al., 2012; Van Gelder et al., 2013, 2015), it is expected that the activation of future self-continuity results in lower endorsement/higher condemnation of the COVID-19 safety violations than a) the proximal future self and $b$ ) other people. Third, goal commitment can be used to explain the intention-behaviour gap (Ajzen, 1991; Gollwitzer, 1999; Sheeran et al., 2005; Sutton, 1998). If one is more committed to goal pursuit, they will form stronger intentions to implement appropriate behaviours. Thus, it is expected that goal commitment has a positive effect on a) adherence intentions and b) safety violations condemnation. An experimental study was conducted to test these hypotheses.

\section{Method}

\section{Participants}

The sample size was determined by identifying the number of participants needed for the $F$ test to have enough power to detect a significant effect. The effect size was determined based on the effect sizes reported in studies that examined similar hypotheses (see the overview of the present study). For 3 groups, $\alpha=.05$, $1-\beta=.80$, and $\eta^{2}=.06$ (a medium-size effect; Cohen, 1988) approximately 58 participants per experimental group were needed. To be eligible for participation, all participants needed to be fluent in Bosnian/Serbian/Croatian. A total of 199 participants accessed the online study, out of which $184\left(n_{\text {male }}=74, n_{\text {female }}=110\right)$ chose to participate in the study. The mean age of participants who finished the study was $28(M=27.53, S D=11.09$, $\operatorname{Min}=15$, Max $=65)$.

\section{Materials and Procedure}

All participants were recruited via an online link that was shared on social media, mailing lists, and internet forums. The link acted as a random redirector to 
one of three questionnaire forms. They were identical in all aspects except for the experimental manipulation. The first part of the questionnaire required the participants to report relevant demographic information: age, gender, nationality, educational level, employment status, and whether they lived in a city or a smaller town. Then, participants were asked to provide further information about their situation during the COVID-19 outbreak: the length of COVID-19 measures in their living area, household members they live with, and whether they resided abroad when the COVID-19 epidemic began. In the last section of the preliminary questionnaire part, participants reported their current levels of COVID-19 safety measures adherence (safety measures had been implemented between one and three weeks before data collection began, depending on the part of the country). A scale was created for this study and consisted of behaviours which the Federal Headquarters of Civil Protection of the Federation of Bosnia and Herzegovina (2020, p. 1) deemed relevant. Participants were asked to indicate how much they adhered to the safety measures on a 7-point scale $(1=$ does not apply to me at all, $7=$ completely applies to me). The behaviours included: staying at home whenever possible, not participating in public gatherings, frequent washing of hands, keeping a social distance of 1.5 meters, and immediately reporting COVID-19 symptoms to relevant authorities. The alpha coefficient for the scale was $\alpha=.85$, indicating good internal consistency.

Experimental manipulation. The manipulation followed a similar procedure as the letter-writing task in Study 1 by Van Gelder et al. (2013). Participants were randomly allocated to 3 different conditions. In the first condition, participants received instructions that this study focuses on the perception of other people. They were asked to describe their best friend with a focus on their life philosophy and the things their friend finds important in 200-300 words. The second experimental condition included the activation of the proximal future self. The participants were told that the study aims to understand how individuals see themselves in the future. Participants in this condition were instructed to write a 200 to 300 -word letter to their future self in 3 months, focusing on their current worldview and the things they deem relevant. Finally, the last experimental group included the manipulation of the distant future self. Participants received the same instructions as in Condition 2, but were asked to write a letter to their self, 10 years in the future. After completing the letterwriting task, relevant dependent and manipulation check variables were measured. A brief description of the measures follows.

Future Self-Continuity Scale. The Future Self-Continuity Scale (ErsnerHershfield et al., 2009) was used as a manipulation check. The scale is a modified version of Aron et al.'s (1992) Inclusion of the Other in the Self Scale. It is a singleitem measure of future self-continuity. Seven pairs of Euler circles are presented, with each following a pair containing a higher overlap between the circles presenting the present and future self, respectively. Participants are asked to indicate the level they feel connected to their future self in 10 years by choosing one of the possible 
circle pairs. Ersner-Hershfield et al. (2009) demonstrated that the scale has good testretest reliability over 2 weeks $(r=.66)$.

Safety Measures Adherence Intention. A specific scale was constructed to measure the behavioural intentions to respect COVID-19 safety measures. As with the pre-manipulation measure, this scale consisted of the same behaviours that were recommended by civil protection authorities. This time, participants were asked to report their intentions to adhere on a 7 -point scale $(1=$ not at all, $7=$ completely $)$. Participants with high scores show a high intention to adhere, while lower scores indicate the opposite. The scale showed acceptable internal consistency, $\alpha=.78$. A principal component analysis was run to inspect the structure of this measure, while Parallel analysis (Horn, 1965) was used to determine the number of components for extraction. Only one component had an eigenvalue larger than the eigenvalue generated from random data. The loadings on all items were satisfactorily ranging from .80 to .91 .

The Goal Commitment Scale. Goal commitment was measured with a modified version of the Goal Commitment Scale (Hollenbeck, Klein et al., 1989; Hollenbeck, Williams et al., 1989). It is an 8-item instrument used to measure the extent to which one is committed to a specific goal. The original authors reported good internal consistency $(\alpha=.88)$, and the items were primarily loaded on 1 factor. The items' content was modified by replacing the target word "goal" with "COVID-19 safety measures". Participants were asked to respond to how much they agree/disagree about the statements regarding the commitment to COVID-19 safety measures on a 7 -point scale $(1=$ completely disagree, $7=$ completely agree $)$. Higher scores indicate higher goal commitment. The reported alpha for the modified coefficient was slightly larger than in the original study, $\alpha=.90$. Parallel analysis revealed that only one component should be retained. Component loadings of the specific items ranged between .43 and .86 .

COVID-19 Safety Measures Violations Endorsement/Condemnation. The scale was developed to measure the tendency to punish irresponsible behaviour. Participants were asked to determine a fine appropriate for safety measures violations. The following behaviours were included: participation in public gatherings, going outside while having COVID-19 symptoms, not respecting the self-isolation measures, not wearing safety equipment (mask and gloves), leaving home during curfew hours. Safety measures violations could be fined on a scale ranging from 0 to 500 convertible marks ([KM], approximately 255 euro). The mentioned scale was used instead of a Likert alternative to increase the ecological validity of the procedure. Higher fines indicated a more strict approach to violations and thus more endorsement of responsible behaviour. On the other hand, lower fines reflected a more relaxed stance towards violations and less approval of responsible behaviour. Internal consistency assessed using the alpha coefficient was good, $\alpha=.86$. Once again, the parallel analysis showed a one-component solution to be the most viable. The individual item loadings ranged from .75 to .79 . 


\section{Results}

\section{Randomization Check}

Experimental groups were compared on demographic and behavioural variables related to the COVID-19 pandemic. Chi-squared tests were used to examine the relationship between groups and categorical demographic variables, while differences on continuous variables were inspected with a one-factor ANOVA. The groups did not differ in the duration of restrictive measures for individual respondents, $\chi^{2}(6)=5.03, p=.540, V=.165$. Furthermore, the frequency distribution of respondents living alone, with family, a partner, or with roommates was not different among groups, $\chi^{2}(6)=2.52, p=.866, V=.117$. Respondents were evenly distributed according to their previous behaviours related to COVID-19 protection measures, $F(2,182)=1.89, p=.154, \eta^{2}=.020$. Only the number of the respondents who stayed abroad during the outbreak of the pandemic was not evenly distributed among groups, $\chi^{2}(2)=7.75, p=.020, V=.205$. The first $(16.13 \%)$ and third $(11.48 \%)$ groups included more respondents who returned to their country from abroad during the restrictive measures than the other-people group (1.61\%).

\section{Manipulation Check}

A one-factor ANOVA was conducted to examine the differences between the groups on the Future Self Continuity Scale. The groups differed significantly, $F(2$, $181)=3.36, p=.038, \eta^{2}=.036$. As a follow-up analysis simple contrasts were used to compare the third experimental groups to the other two. The mean continuity with the self, 10 years in the future differs between the third $(M=4.16, S D=1.64)$ and first group $(M=3.43, S D=1.64), t(181)=2.51, p=.007$ (one-tailed), $d=0.449$. The third group differed from the first one $(M=3.65, S D=1.58)$ as well, $t(181)=1.78$, $p=.039$ (one-tailed), $d=0.332$. Respondents who wrote a letter to the distant future self, showed a greater connection to the 10 -years future self than other respondents. The experimental manipulation was successful.

\section{Descriptive Statistics}

In Table 1 relevant descriptive statistics for the study variables are presented for the 3 experimental groups. Respondents showed above average adherence to safety measures $(M=5.59, S D=1.58)$, and were committed to behaviours that are in line with safety measures $(M=5.89, S D=0.95)$. Also, the average fine for undesirable behaviours during the COVID-19 pandemic for this sample was $321 \mathrm{KM}(M=$ $321.39, S D=138.62$ ). 


\section{Table 1}

Descriptive Statistics of the Study Variables

\begin{tabular}{|c|c|c|c|c|c|c|c|c|}
\hline Variable & Group & $N$ & $M(S E)$ & $S D$ & Min & Max & Skew. & Kurt. \\
\hline \multirow{4}{*}{ Intentions } & $\begin{array}{l}\text { Other } \\
\text { people }\end{array}$ & 61 & $5.88 \quad(0.18)$ & 1.44 & 2.60 & 7 & -1.23 & 0.03 \\
\hline & $\begin{array}{l}\text { Proximal } \\
\text { future self }\end{array}$ & 62 & $5.01 \quad(0.22)$ & 1.72 & 2.20 & 7 & -0.21 & -1.58 \\
\hline & $\begin{array}{l}\text { Distant } \\
\text { future self }\end{array}$ & 61 & $5.88 \quad(0.18)$ & 1.43 & 2.80 & 7 & -1.22 & -0.03 \\
\hline & $\sum$ & 184 & $5.59 \quad(0.12)$ & 1.58 & 2.20 & 7 & -0.84 & -0.88 \\
\hline \multirow{4}{*}{ Condemnation } & $\begin{array}{l}\text { Other } \\
\text { people }\end{array}$ & 61 & 317.21 (17.88) & 139.66 & 40.00 & 500 & -0.69 & -0.78 \\
\hline & $\begin{array}{l}\text { Proximal } \\
\text { future self }\end{array}$ & 62 & $269.90(17.33)$ & 136.48 & 0 & 500 & -0.07 & -1.22 \\
\hline & $\begin{array}{l}\text { Distant } \\
\text { future self }\end{array}$ & 61 & 377.90 (15.24) & 119.01 & 0 & 500 & -1.10 & 1.17 \\
\hline & $\bar{\Sigma}$ & 184 & $321.39(10.22)$ & 138.62 & 0 & 500 & -0.58 & -0.72 \\
\hline \multirow{4}{*}{ Commitment } & $\begin{array}{l}\text { Other } \\
\text { people }\end{array}$ & 61 & $5.62(0.18)$ & 1.38 & 1.62 & 7 & -1.31 & 0.98 \\
\hline & $\begin{array}{l}\text { Proximal } \\
\text { future self }\end{array}$ & 62 & $4.83 \quad(0.23)$ & 1.85 & 1.00 & 7 & -0.66 & -0.85 \\
\hline & $\begin{array}{l}\text { Distant } \\
\text { future self }\end{array}$ & 61 & $5.89(0.12)$ & 0.95 & 3.38 & 7 & -0.85 & -0.14 \\
\hline & $\sum$ & 184 & $5.44 \quad(0.11)$ & 1.50 & 1.00 & 7 & -1.23 & 0.76 \\
\hline
\end{tabular}

Note. SE - standard error; Skew. - Skewness; Kurt. - Kurtosis.

\section{Differences in COVID-19 Safety Measures Adherence Intentions}

To examine the differences between the experimental groups in the intention to adhere to COVID-19 protection measures, a one-factor ANOVA was performed. The groups were found to be significantly different, $F(2,120.12)=5.86, p=.004$, $\eta^{2}=.068$. Figure 1 presents the differences between the experimental groups according to the intention to adhere to COVID-19 safety measures. Simple contrasts were used to compare the third group to the other two. Results showed that the third group $(M=5.88, S D=1.43)$ showed a greater intention to adhere to safety measures compared to the second group $(M=5.01, S D=1.72), t(117.84)=3.06, p=.002$ (onetailed), $d=0.539$. On the other hand, the first and third experimental groups did not differ, $t(120.00)=.000, p=1.000, d=0.000$. Although the participants in the distant and proximal future self, condition did differ, contrary to expectations, no differences were found between the distant future self and the other people condition.

Also, the mediating role of commitment to COVID-19 measures was identified. When commitment is included in a model containing differences between the first and second experimental groups (dummy coded), and the third and second experimental groups (dummy coded), the direct effects of both independent variables 
lose their statistical significance, $\beta_{1 \mathrm{vs} 2}=0.311, z=1.469, p=.142 ; \beta_{3 \mathrm{vs} 2}=0.121$, $z=0.525, p=.600$. The statistical significance of both indirect effects was examined using the Preacher and Hayes' bootstrapping procedure (Model 4; Hayes \& Preacher, 2014; Preacher \& Hayes, 2008). Non-standardized indirect effects were determined for each of the 10,000 bootstrapped samples, while the $95 \%$ confidence intervals were computed by identifying indirect effects at the 2.5 th and 97.5 th percentiles. As 95\% confidence intervals did not contain zero, the mediation for the first dummy variable $\left(\mathrm{CI}_{95}=0.158,0.958\right)$, and the second dummy variable $\left(\mathrm{CI}_{95}=0.397,1.132\right)$ was statistically significant. Groups that wrote letters to their friend and distant future self, expressed a greater intention to respect the measures through greater goal commitment.

\section{Figure 1}

Mean COVID-19 Safety Measures Adherence Intentions for the 3 Experimental Groups. Error Bars Indicate Standard Errors of the Means.

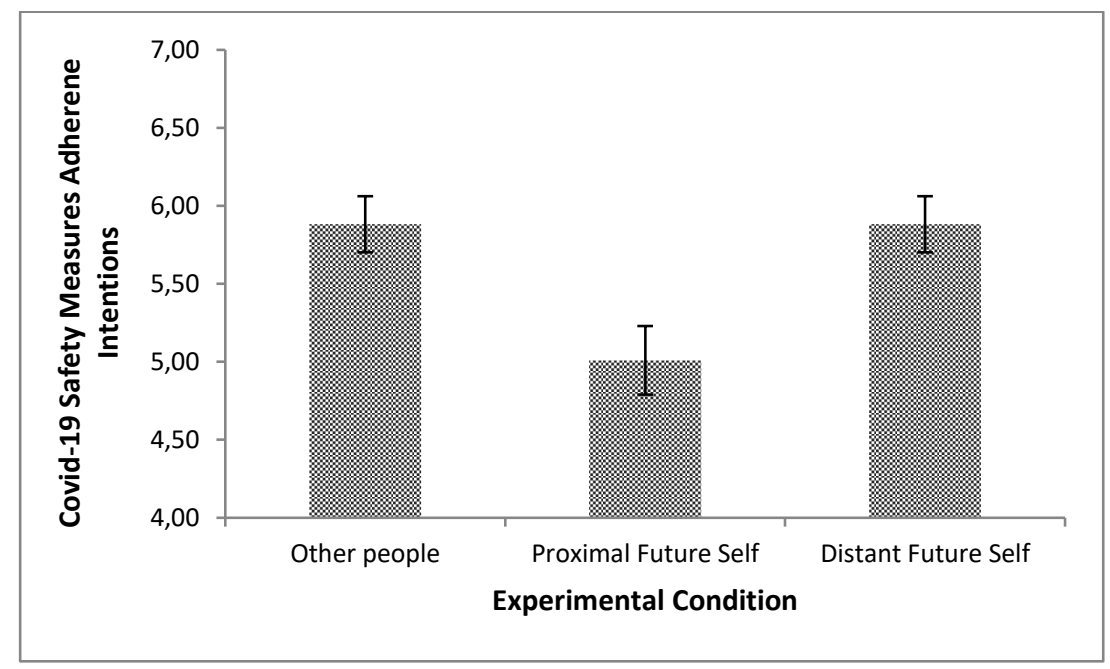

\section{Differences in Condemnation of COVID-19 Safety Measures Violations}

A one-factor ANOVA was conducted to examine group differences in the tendency to impose fines for violations of COVID-19 safeguards. The dependent variable represented the average imposed fine for non-compliance with COVID-19 safety measures. The groups were found to be statistically different, $F(2,181)=$ $10.33, p<.001, \eta^{2}=.102$. Figure 2 shows the differences between the experimental groups based on the dependent variable.

To examine these differences in more detail, simple contrasts compared the third group to the other two. Participants in the third group $(M=377.90, S D=119.01)$ 
imposed greater fines to undesirable behaviours than the respondents in the second group $(M=269.90, S D=136.48), t(181)=4.535, p<.001, d=0.843$. Also, the third experimental group was more strict towards violations of protection measures than the first group $(M=317.21, S D=139.66), t(181)=2.538, p=.006$ (one-tailed), $d=0.468$. In line with the study expectations, the group in which the distant future self was activated showed greater condemnation of undesirable behaviours.

\section{Figure 2}

Mean Values of Assigned Fines For COVID-19 Safety Measures Violations for the 3 Experimental Groups. Error Bars Indicate Standard Errors of the Means.

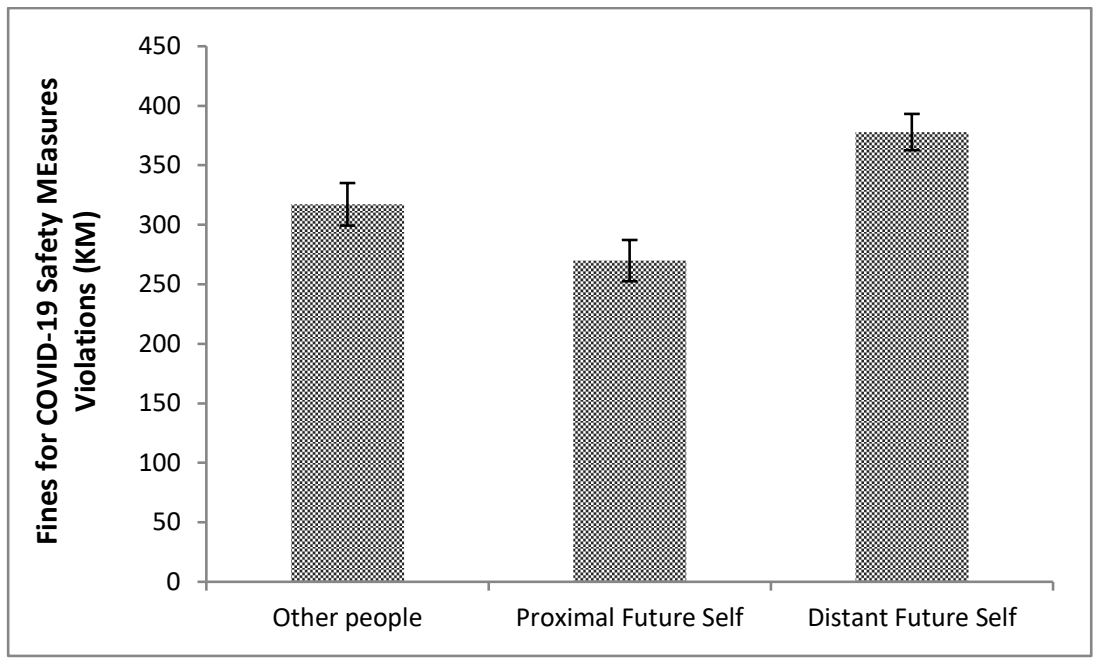

Commitment to COVID-19 measures was a mediator between the independent and dependent variables. The inclusion of commitment in the model containing the differences between the first and the second experimental group (dummy coded) resulted in the effect of this independent variable losing its significance, $\beta_{1 \mathrm{vs} 2}=5.477$, $z=0.274, p=.784$. The significance of the difference between the third and second experimental groups (dummy coded) decreases, but still remains statistically significant, $\beta_{3 \mathrm{vs} 2}=51.990, z=2.641, p=.008$. By applying the bootstrapping procedure (Model 4; Preacher \& Hayes, 2008; Hayes \& Preacher, 2014), the significance of the mediating role of commitment was determined on 10,000 bootstrapped samples by calculating the values of indirect effects at the 2.5th and 97.5th percentiles. The 95\% confidence intervals for the indirect effect of the first dummy variable $\left(\mathrm{CI}_{95}=13.116,72.858\right)$ and the second dummy variable $\left(\mathrm{CI}_{95}=\right.$ $30.375,85.612)$ did not include zero indicating statistical significance. Greater commitment to COVID-19 safety measures mediated group differences in violations condemnation/endorsement. 


\section{Discussion}

An experiment was run to demonstrate that future self-continuity increases COVID-19 safety measures adherence intentions and endorsement. It was expected that increasing the connection to the distant future self would produce higher compliance intentions than connection to the proximal future self and other people. Participants in the distant future self and the other people conditions reported higher adherence intentions than proximal future self participants. This finding is in line with the hypotheses coming from CLT. The activation of the distant future self might have promoted the focus on abstract safety measures rules and regulations (Trope \& Lieberman, 2003, 2010) and increased the responsibility for one's safety in the future (Hershfield, 2011; Parfit, 1984). Contrary to expectations, activation of the future self did not increase compliance intentions when compared to the activation of connectedness with other people. Although the results seem surprising, they can be interpreted from two perspectives. First, other people are also psychologically distant from the self (social distance; Bar-Anan et al., 2006; Trope \& Lieberman, 2010). In that regard, thinking about other people could have produced a similar effect on intentions as thinking about the distant future self. One could decide to wear safety equipment to either not potentially infect other people or to ensure that they will stay healthy in the distant future. Second, intentions could have been a poor measure of responsible behaviour. Previous studies have shown that intentions account for only a modest amount of behaviour variance (Gollwitzer, 1999). Individuals mostly have strong intentions to achieve a goal, but fail to act upon them (Sheeran et al., 2005). While all three groups showed rather strong intentions to adhere, the question remains if intentions would successfully translate into behaviour.

Moreover, it was predicted that the connection with the distant future self would increase the endorsement of the COVID-19 safety measures. In line with this hypothesis, participants who had their distant future self activated were more strict towards safety measures violations than other participants. It is possible that these individuals became sensitive to the negative outcomes of irresponsible behaviour. Being connected to others and the proximal future self resulted in a more relaxed stance towards safety measures violations. In other words, the activation of the distant future self resulted in higher levels of endorsement for safety measures compliance. This finding is in line with previous studies which reported a link with future self connectedness and responsible actions (Hersfield et al., 2012; Van Gelder et al., 2013, 2015). As in these studies, future self-continuity decreased the endorsement of unethical behaviour.

Goal commitment was expected to mediate the relationship between the experimental manipulations with adherence intentions and endorsement. It was found that individuals in the distant future self condition and others had a high commitment to safety measures and thus showed higher adherence intentions than their proximal future self counterparts. The same pattern was found for safety 
measures endorsement. Being connected to the distant future self and other people might have produced a higher commitment to COVID-19 safety measures than being connected to the proximal future self. Higher commitment, in turn, resulted in higher levels of adherence intentions and less endorsement of safety violations. It was demonstrated that higher commitment leads to stronger intentions to perform goalrelated behaviour (Gollwitzer, 1999; Sutton, 1998). Furthermore, in line with perspectives which highlight the importance of future self-continuity for responsible decision-making (Bartels \& Rips, 2010; Parfit, 1984), individuals who are more concerned about the well-being of their future selves will show higher levels of attachment towards goals that ensure one's safety in the future. These goals are deemed worthy of being committed to.

This experiment has one important practical implication: increasing the connection to the future self may lead to more compliance with safety measures, rules, and norms. By addressing the long-term benefits of adherence for the future self, policymakers can facilitate a more future-oriented mindset in individuals and, thus, more consideration of consequences during decision-making. To be more specific, promoting the responsibility for one's future self may result in better policy compliance rates. Although it was not the primary aim of the study, it was identified that highlighting the connection to others leads to a similar, albeit less strong effect. The current study provided further evidence of current theoretical notions that increasing future self-continuity leads to ethical and responsible decision-making (Bartels \& Urminsky, 2011; Hershfield et al., 2012; Van Gelder et al., 2013, 2015). Moreover, a mechanism through which future self-continuity could affect behaviour was identified. Goal commitment, the level of one's attachment to the pursued goal (Hollenbeck, Klein et al., 1989; Hollenbeck, Williams et al., 1989), is a factor that enabled participants of this study to transfer their concern for the well-being of their future self into intentions to adhere and endorse safety measures. By being more committed to safety measures, one could resist the urges of short-term benefits that come with behaving carelessly. Finally, the ecological validity of this experimental design further strengthens the importance of these findings. The dependent variables were related to current issues concerning the COVID-19 crisis, and the items' content mirrored the problems and behaviours prevalent in participants' environment during data collection.

This study is not without its limitations. First, as was previously stated, intention strength could have been a poor measure of safety measures adherence. Forming strong intentions does not always translate into intention-congruent behaviour (e.g., Gollwitzer, 1999; Trope \& Liberman, 2003, 2010). One should generalize the findings of this study to actual behaviour with caution. Second, Bartels and Rips (2010) found that future self-continuity follows a normal distribution. This study failed to control for individual differences in this variable. A certainly viable explanation could be that some participants were simply more connected to their future selves, no matter the experimental condition. The safety measures used in this 
study were based on the decisions made by the governing bodies in Bosnia and Herzegovina. It is not recommended to generalize the findings or use the constructed scales in countries that handled the crisis differently (e.g., some states did not proclaim a mandatory curfew). Finally, the groups had an unequal number of participants who resided abroad during the start of the upbreak. It is possible that the mandatory self-isolation that these participants had to go through influenced the differences between the groups.

The directions for future research are related to the study limitations. The temporal generalizability of the findings was beyond the scope of this research design. Future studies should adopt a longitudinal design to test whether the effect of future self-continuity on safety measures adherence remains stable over time. Longitudinal studies are a better way of dealing with individual differences, and one could include behavioural measures as dependent variables. Hershfield (2011) assumed that three components of future self-continuity exist: similarity, vividness, and positive affect. Recently, Sokol and Serper (2019) psychometrically validated an instrument to measure said constructs. This study applied a similar approach as Van Gelder et al. (2013) and focused on manipulating vividness. An open question remains on the effect of the other 2 components on adherence. Moreover, this study did not differentiate goal commitment from other constructs that were found to be relevant in goal pursuit, namely goal instrumentality (Yukl \& Latham, 1978) and energization (Gollwitzer et al., 1990). More elaborate designs are needed to answer how the mentioned goal-related mechanisms mediate the relationship between future self-continuity and adherence. Finally, this paper focused on an extreme example that was in power during an event that affected the world on a global scale. More research is needed to understand whether these findings can be replicated to everyday safety measures (e.g., safety measures in the workplace).

This current study demonstrated that making psychologically distant concepts more vivid could facilitate higher levels of responsible behaviour. Interventions based on making the distant future self feel closer are an effective way of dealing with careless actions. By considering that our actions might hurt someone in the future, we become more responsible in the present.

\section{References}

Ainslie, G. (1975). Specious reward: A behavioral theory of impulsiveness and impulse control. Psychological Bulletin, 82(4), 463-496. https://doi.org/10.1037/h0076860

Ajzen, I. (1991). The Theory of Planned Behavior. Organizational Behavior and Human Decision Procceses, 50, 179-211. https://doi.org/10.1016/0749-5978(91)90020-T 
Arantes, J., Berg, M. E., Lawlor, D., \& Grace, R. C. (2013). Offenders have higher delaydiscounting rates than non-offenders after controlling for differences in drug and alcohol abuse. Legal and Criminological Psychology, 18(2), 240-253. https://doi.org/10.1111/j. 2044-8333.2012.02052.x

Aron, A., Aron, E. N., \& Smollan, D. (1992). Inclusion of Other in the Self Scale and the structure of interpersonal closeness. Journal of Personality and Social Psychology, 63(4), 596-612. https://doi.org/10.1037/0022-3514.63.4.596

Audrain-McGovern, J., Rodriguez, D., Epstein, L. H., Cuevas, J., Rodgers, K., \& Wileyto, E. P. (2009). Does delay discounting play an etiological role in smoking or is it a consequence of smoking? Drug and Alcohol Dependence, 103(3), 99-106. https://doi.org/10.1016/j.drugalcdep.2008.12.019

Bar-Anan, Y., Liberman, N., \& Trope, Y. (2006). The association between psychological distance and construal level: Evidence from an implicit association test. Journal of Experimental Psychology: General, 135(4), 609-622. https://doi.org/10.1037/00963445.135.4.609

Bartels, D. M., \& Rips, L. J. (2010). Psychological connectedness and intertemporal choice. Journal of Experimental Psychology: General, 139(1), 49-69. https://doi.org/10.1037/ a0018062

Bartels, D. M., \& Urminsky, O. (2011). On intertemporal selfishness: How the perceived instability of identity underlies impatient consumption. Journal of Consumer Research, 38(1), 182-198. https://doi.org/10.1086/658339

Bartels, D. M., \& Urminsky, O. (2015). To know and to care: How awareness and valuation of the future jointly shape consumer spending. Journal of Consumer Research, 41(6), 1469-1485. https://doi.org/10.1086/680670

Benzion, U., Rapoport, A., \& Yagil, J. (1989). Discount rates inferred from decisions: An experimental study. Management Science, 35(3), 270-284.

Burum, B. A., Gilbert, D. T., \& Wilson, T. D. (2016). Becoming stranger: When future selves join the out-group. Journal of Experimental Psychology: General, 145(9), 1132-1140. https://doi.org/10.1037/xge0000193

Chapman, G. B., \& Elstein, A. S. (1995). Valuing the future: Temporal discounting of health and money. Medical Decision Making, 15(4), 373-386. https://doi.org/10.1177/ 0272989X9501500408

Chesson, H. W., Leichliter, J. S., Zimet, G. D., Rosenthal, S. L., Bernstein, D. I., \& Fife, K. H. (2006). Discount rates and risky sexual behaviors among teenagers and young adults. Journal of Risk and Uncertainty, 32(3), 217-230. https://doi.org/10.1007/s11166-0069520-1

Cohen, J. (1988). Statistical power analysis for the behavioral sciences (2nd ed). L. Erlbaum Associates.

Elster, J. (1985). Weakness of will and the free-rider problem. Economics and Philosophy, l(2), 231-265. https://doi.org/10.1017/S0266267100002480 
Ersner-Hershfield, H., Wimmer, G. E., \& Knutson, B. (2009). Saving for the future self: Neural measures of future self-continuity predict temporal discounting. Social Cognitive and Affective Neuroscience, 4(1), 85-92. https://doi.org/10.1093/scan/nsn042

Federal Headquaters of Civil Protection of Federation of Bosnia and Herzegovina. (2020). Naredba o zabrani kretanja građana na području FbiH od 20:00 do 5:00. https://fbihvlada.gov.ba/file/Naredba\%2036-1.pdf

Frederick, S., Loewenstein, G., \& O’Donoghue, T. (2002). Time discounting and time preference: A critical review. Journal of Economic Literature, 40(2), 351-401. https://doi.org/10.1257/002205102320161311

Frederick, S., Novemsky, N., Wang, J., Dhar, R., \& Nowlis, S. (2009). Opportunity cost neglect. Journal of Consumer Research, 36(4), 553-561. https://doi.org/10.1086/ 599764

Fujita, K., \& Han, H. A. (2009). Moving beyond deliberative control of impulses: The effect of construal levels on evaluative associations in self-control conflicts. Psychological Science, 20(7), 799-804. https://doi.org/10.1111/j.1467-9280.2009.02372.x

Fujita, K., Trope, Y., Liberman, N., \& Levin-Sagi, M. (2006). Construal levels and selfcontrol. Journal of Personality and Social Psychology, 90(3), 351-367. https://doi.org/ 10.1037/0022-3514.90.3.351

Gollwitzer, P. M. (1999). Implementation intentions: Strong effects of simple plans. American Psychologist, 54(7), 493-503. https://doi.org/10.1037/0003-066X.54.7.493

Gollwitzer, P. M., Heckhausen, H., \& Ratajczak, H. (1990). From weighing to willing: Approaching a change decision through pre- or postdecisional mentation. Organizational Behavior and Human Decision Processes, 45(1), 41-65. https://doi.org/ 10.1016/0749-5978(90)90004-S

Hayes, A. F., \& Preacher, K. J. (2014). Statistical mediation analysis with a multicategorical independent variable. British Journal of Mathematical and Statistical Psychology, 67(3), 451-470. https://doi.org/10.1111/bmsp.12028

Hershfield, H. E. (2011). Future self-continuity: How conceptions of the future self transform intertemporal choice. Annals of the New York Academy of Sciences, 1235(1), 30-43. https://doi.org/10.1111/j.1749-6632.2011.06201.x

Hershfield, H. E., Cohen, T. R., \& Thompson, L. (2012). Short horizons and tempting situations: Lack of continuity to our future selves leads to unethical decision making and behavior. Organizational Behavior and Human Decision Processes, 117(2), 298-310. https://doi.org/10.1016/j.obhdp.2011.11.002

Hershfield, H. E., Goldstein, D. G., Sharpe, W. F., Fox, J., Yeykelis, L., Carstensen, L. L., \& Bailenson, J. N. (2011). Increasing saving behavior through age-progressed renderings of the future self. Journal of Marketing Research, 48(SPL), S23-S37. https://doi.org/10. 1509/jmkr.48.SPL.S23

Hollenbeck, J. R., Klein, H. J., O’Leary, A. M., \& Wright, P. M. (1989). Investigation of the construct validity of a self-report measure of goal commitment. Journal of Applied Psychology, 74(6), 951-956. https://doi.org/10.1037/0021-9010.74.6.951 
Hollenbeck, J. R., Williams, C. R., \& Klein, H. J. (1989). An empirical examination of the antecedents of commitment to difficult goals. Journal of Applied Psychology, 74(1), 18 23. https://doi.org/10.1037/0021-9010.74.1.18

Horn, J. L. (1965). A rationale and test for the number of factors in factor analysis. Psychometrika, 30, 179-185. https://doi.org/10.1007/BF02289447

Kirby, K. N. (1997). Bidding on the future: Evidence against normative discounting of delayed rewards. Journal of Experimental Psychology: General, 126(1), 54-70. https://doi.org/10.1037/0096-3445.126.1.54

Kirby, K. N., \& Maraković, N. N. (1995). Modeling myopic decisions: Evidence for hyperbolic delay-discounting within subjects and amounts. Organizational Behavior and Human Decision Processes, 64(1), 22-30. https://doi.org/10.1006/obhd.1995.1086

Liberman, N., \& Trope, Y. (1998). The role of feasibility and desirability considerations in near and distant future decisions: A test of temporal construal theory. Journal of Personality and Social Psychology, 75(1), 5-18. https://doi.org/10.1037/0022-3514. 75.1 .5

Locke, E. A., \& Latham, G. P. (1990). A theory of goal setting \& task performance. Prentice Hall.

Locke, E. A., \& Latham, G. P. (2002). Building a practically useful theory of goal setting and task motivation: A 35-year odyssey. American Psychologist, 57(9), 705-717. https://doi.org/10.1037/0003-066X.57.9.705

Loewenstein, G. (1996). Out of control: Visceral influences on behavior. Organizational Behavior and Human Decision Processes, 65(3), 272-292. https://doi.org/10.1006/ obhd.1996.0028

Malkoc, S. A., \& Zauberman, G. (2006). Deferring versus expediting consumption: The effect of outcome concreteness on sensitivity to time horizon. Journal of Marketing Research, 43(4), 618-627. https://doi.org/10.1509/jmkr.43.4.618

Moore, S. C., \& Cusens, B. (2010). Delay discounting predicts increase in blood alcohol level in social drinkers. Psychiatry Research, 179(3), 324-327. https://doi.org/10.1016/j. psychres.2008.07.024

Parfit, D. (1971). Personal identity. The Philosophical Review, 80(1), 3-27. https://doi.org/10. $2307 / 2184309$

Parfit, D. (1984). Reasons and persons. Clarendon Press.

Preacher, K. J., \& Hayes, A. F. (2008). Asymptotic and resampling strategies for assessing and comparing indirect effects in multiple mediator models. Behavior Research Methods, 40(3), 879-891. https://doi.org/10.3758/BRM.40.3.879

Pronin, E., \& Ross, L. (2006). Temporal differences in trait self-ascription: When the self is seen as an other. Journal of Personality and Social Psychology, 90(2), 197-209. https://doi.org/10.1037/0022-3514.90.2.197 
Pronin, E., Olivola, C. Y., \& Kennedy, K. A. (2008). Doing unto future selves as you would do unto others: Psychological distance and decision making. Personality and Social Psychology Bulletin, 34(2), 224-236. https://doi.org/10.1177/0146167207310023

Reluga, T. C. (2010). Game theory of social distancing in response to an epidemic. PLoS Computational Biology, 6(5). https://doi.org/10.1371/journal.pcbi.1000793

Samuelson, P. A. (1937). A note on measurement of utility. The Review of Economic Studies, 4(2), 155-161. https://doi.org/10.2307/2967612

Schelling, T. C. (1984). Self-Command in practice, in policy, and in a theory of rational choice. The American Economic Review, 74(2), 1-11.

Sheeran, P., Webb, T. L., \& Gollwitzer, P. M. (2005). The interplay between goal intentions and implementation intentions. Personality and Social Psychology Bulletin, 31(1), 8798. https://doi.org/10.1177/0146167204271308

Sheffer, C., MacKillop, J., McGeary, J., Landes, R., Carter, L., Yi, R., Jones, B., Christensen, D., Stitzer, M., Jackson, L., \& Bickel, W. (2012). Delay discounting, locus of control, and cognitive impulsiveness independently predict tobacco dependence treatment outcomes in a highly dependent, lower socioeconomic group of smokers. The American Journal on Addictions, 21(3), 221-232. https://doi.org/10.1111/j.1521-0391.2012.00224.X

Sokol, Y., \& Serper, M. (2019). Development and validation of a Future Self-Continuity Questionnaire: A preliminary report. Journal of Personality Assessment, 1-12. https://doi.org/10.1080/00223891.2019.1611588

Sutton, S. (1998). Predicting and explaining intentions and behavior: How well are we doing? Journal of Applied Social Psychology, 28(15), 1317-1338. https://doi.org/10.1111/j. 1559-1816.1998.tb01679.x

Thaler, R. (1981). Some empirical evidence on dynamic inconsistency. Economics Letters, 8(3), 201-207. https://doi.org/10.1016/0165-1765(81)90067-7

Thaler, R. H., \& Shefrin, H. M. (1981). An economic theory of self-control. Journal of Political Economy, 89(2), 392-406. https://doi.org/10.1086/260971

Trope, Y., \& Liberman, N. (2003). Temporal construal. Psychological Review, 110(3), 403421. https://doi.org/10.1037/0033-295X.110.3.403

Trope, Y., \& Liberman, N. (2010). Construal-Level theory of psychological distance. Psychological Review, 117(2), 440-463. https://doi.org/10.1037/a0018963

Trope, Y., Liberman, N., \& Wakslak, C. (2007). Construal levels and psychological distance: Effects on representation, prediction, evaluation, and behavior. Journal of Consumer Psychology: The Official Journal of the Society for Consumer Psychology, 17(2), 8395. https://doi.org/10.1016/S1057-7408(07)70013-X

Van Gelder, J.L., Hershfield, H. E., \& Nordgren, L. F. (2013). Vividness of the future self predicts delinquency. Psychological Science, 24(6), 974-980. https://doi.org/10.1177/ 0956797612465197 
Van Gelder, J.L., Luciano, E. C., Kranenbarg, M. W., \& Hershfield, H. E. (2015). Friends with my future self: Longitudinal vividness intervention reduces delinquency. Criminology, 53(2), 158-179. https://doi.org/10.1111/1745-9125.12064

World Health Organization (2020). COVID-19 Situation Report - 113. Retreived from https://reliefweb.int/report/world/coronavirus-disease-covid-19-situation-report-11312-may-2020

Yi, R., Mitchell, S. H., \& Bickel, W. K. (2010). Delay discounting and substance abusedependence. In G. J. Madden \& W. K. Bickel (Eds.), Impulsivity: The behavioral and neurological science of discounting (pp. 191-211). American Psychological Association. https://doi.org/10.1037/12069-007

Yi, R., Stuppy-Sullivan, A., Pickover, A., \& Landes, R. D. (2017). Impact of construal level manipulations on delay discounting. PLoS ONE, 12(5). https://doi.org/10.1371/journal. pone. 0177240

Yukl, G. A., \& Latham, G. P. (1978). Interrelationships among employee participation, individual differences, goal difficulty, goal acceptance, goal instrumentality, and performance. Personnel Psychology, 31(2), 305-323. https://doi.org/10.1111/j.17446570.1978.tb00449.x

Zauberman, G., Kim, B. K., Malkoc, S. A., \& Bettman, J. R. (2009). Discounting time and time discounting: Subjective time perception and intertemporal preferences. Journal of Marketing Research, 46(4), 543-556. https://doi.org/10.1509/jmkr.46.4.543

\title{
Kontinuitet s budućim ja povećava odgovornost tijekom ograničenja povezanih s bolešću COVID-19
}

\begin{abstract}
Sažetak
Neodgovorno ponašanje u sadašnjosti povezano je s nemogućnošću razmatranja budućih posljedica. Proveden je eksperiment da bi se ispitalo utječe li zamišljanje budućega sebe na poštivanje i odobravanje sigurnosnih mjera zaštite od bolesti COVID-19. Ukupno 184 ispitanika bila su nasumična raspoređena u 3 skupine. Ovisno o eksperimentalnome uvjetu, ispitanici su imali zadatak napisati pismo drugim ljudima (svojim prijateljima), bliskomu budućem ja i dalekomu budućem ja. Ispitanici u uvjetima udaljenoga budućeg ja i drugih ljudi pokazali su veće namjere pridržavanja mjera od ispitanika u uvjetu bliskoga budućeg ja. Nisu pronađene razlike između udaljenoga budućeg ja i drugih ljudi. Daljnje međugrupne razlike utvrđene su u odobravanju sigurnosnih mjera, pri čemu je grupa koja je zamišljala daleko buduće ja pokazala veće tendencije osuđivanja kršenja mjera od drugih dviju grupa. Predanost mjerama sigurnosti zaštite od bolesti COVID-19 bila je medijator grupnim razlikama za obje zavisne varijable. Rezultati se raspravljaju u okviru teorije konstrukcijskoga nivoa i modela kontinuiteta s budućim ja.
\end{abstract}

Ključne riječi: kontinuitet $\mathrm{s}$ budućim ja, namjere, odgovorno ponašanje, ciljna predanost, sigurnosne mjere zaštite od bolesti COVID-19

Primljeno: 29. 5. 2020. 
